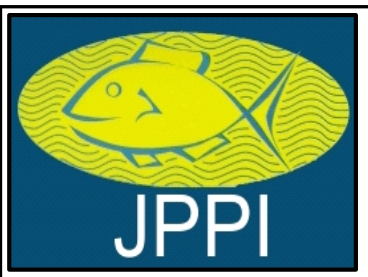

Tersedia online di: http://ejournal-balitbang.kkp.go.id/index.php/jppi

e-mail:jppi.puslitbangkan@gmail.com

JURNAL PENELITIANPERIKANANINDONESIA

Volume 26 Nomor 2 Juni 2020

p-ISSN: 0853-5884

e-ISSN: 2502-6542

Nomor Akreditasi RISTEKDIKTI: 21/E/KPT/2018

\title{
ESTIMASI PARAMETER POPULASI DAN RASIO POTENSI PEMIJAHAN TONGKOL KOMO (Euthynnus affinis, Cantor 1849) DI PERAIRAN SELATAN LOMBOK
}

\section{ESTIMATION ON POPULATION PARAMETERS AND SPAWNING POTENTIAL RATIO OF KAWAKAWA (Euthynnus affinis, Cantor 1849) IN THE SOUTHERN LOMBOK WATERS}

\author{
Arief Wujdi ${ }^{* 1}$, Hety Hartaty' dan Bram Setyadji' \\ 'Loka Riset Perikanan Tuna. Jalan Mertasari No.140, Banjar Suwung Kangin, Denpasar Selatan, Bali, Indonesia \\ Teregistrasi I tanggal: 12 Mei 2020; Diterima setelah perbaikan tanggal: 15 Juni 2020; \\ Disetujui terbit tanggal: 18 Juni 2020
}

\begin{abstract}
ABSTRAK
Tongkol komo (Euthynnus affinis) merupakan salah satu komoditas ekonomis tinggi perikanan tuna neritik, terutama bagi armada tuna skala kecil. Seiring dengan meningkatnya intensitas penangkapan pada satu dekade terakhir, diperlukan kajian kuantitatif terkait keberlangsungan stok. Akan tetapi, minimnya data yang tersedia pada perikanan jenis ini merupakan tantangan terbesar dalam melakukan usaha pengelolaan. Penelitian ini bertujuan untuk menduga parameter populasi dan rasio potensi pemijahan (SPR) berbasis ukuran panjang, sebagai titik acuan biologis kondisi stok dalam menghadapi tekanan penangkapan. Total 1.321 data ukuran panjang dikumpulkan secara acak setiap bulan selama Januari hingga Desember 2016 di Tanjung Luar. Parameter populasi meliputi pertumbuhan, kematian, rekrutmen, dan laju pemanfaatan diestimasi dengan metode ELEFAN. Analisis SPR juga dilakukan dengan melibatkan parameter reproduksi yang disintesis dari penelitian sebelumnya dengan paket LB-SPR. Hasil penelitian menunjukkan bahwa formula pertumbuhan von Bertalanffy diekspresikan dengan persamaan $L t=85,0\left(1-e^{-0,7(t+0,173)}\right)$. Meskipun rata-rata sampel tongkol komo diprediksi telah matang gonad/memijah $\left(S L_{50}>L_{50}\right)$, namun sumberdaya tongkol komo mengalami tekanan yang tergolong tinggi dan mengganggu rekrutmen individu baru ke dalam stok yang diindikasikan dengan parameter lainnya seperti rasio mortalitas penangkapan relatif $(F / M)=2,15$, laju eksploitasi $(E)=0,68$, dan $S P R=23 \%$. Oleh karena itu, diperlukan penyusunan pengelolaan yang efektif untuk kelestarian perikanan.
\end{abstract}

Kata Kunci: Tongkol komo; skala kecil; ELEFAN; LB-SPR; pengkajian stok

\begin{abstract}
Eastern little tuna or commercially known as kawakawa is listed as one of the most economically important species of neritic tuna, especially caught by small-scale tuna fisheries. Increasing fishing pressure in the last decade should be responded by a quantitative analysis on its stock. The problem arises when this typical fishery usually possesses limited time-series data. This study intended to estimate population parameters and spawning potential ratio (SPR) as a biological reference point to state the healthiness of fishery corresponding to the fishing pressure around coastal areas. A total of 1,321 length measurement data were randomly sampled monthly from January to December 2016 in Tanjung Luar. Population parameters including growth, mortality, recruitment, and exploitation rate were estimated by applying the ELEFAN method. SPR analysis was also carried out by involving reproduction parameters synthesized from previous studies using the LBSPR package. The results showed that the von Bertalanffy growth functions were expressed by the equation $L t=85.0\left(1-e^{-0.7(t+0.173)}\right)$. Although the majority of kawakawa was predicted in maturity as indicated by $S L_{50}>L_{50}$, high exploitation has occurred to the fishery that can be interfered the recruitment to the stock, as confirmed by other parameters, such as relative fishing
\end{abstract}


mortality $(F / M)=2.15$, exploitation rate $(E)=0.68$, and $S P R=23 \%$. Hence, the establishment of appropriate management strategies is needed to aim fishery sustainability.

\section{Keywords: Eastern little tuna; small-scale; ELEFAN; LB-SPR; stock assessment}

\section{PENDAHULUAN}

Tongkol komo (Euthynnus affinis) termasuk anggota famili Scombridae yang digolongkan ke dalam jenis tuna neritik. Habitatnya meliputi perairan pantai di daerah tropis dan subtropis (Chiou \& Lee, 2004; Rohit et al., 2012). Tongkol komo hidup bergerombol dengan ikan yang seukuran dari anggota Scombridae lainnya dan tertangkap dengan berbagai alat tangkap (Ahmed et al., 2015), yang didominasi oleh jaring insang, pancing ulur dan tonda, serta pukat cincin (IOTC, 2019). Diantara jenis tuna neritik, hasil tangkapan tongkol komo termasuk yang paling melimpah. Produksi tongkol komo berkontribusi sebesar 159 ribu ton atau 26,1\% dari keseluruhan hasil tangkapan tuna neritik di Samudra Hindia, yaitu sebesar 610 ribu ton (IOTC, 2019). Jumlah tersebut diikuti oleh tangkapan tengiri (Scomberomorus commerson) sebesar 158 ribu ton (25,9\%), tongkol abu-abu (Thunnus tonggol) 139 ribu (22,8\%), dan tongkol krai (Auxis thazard) 84 ribu ton $(13,9 \%)$. Secara keseluruhan, status stok tongkol komo di Samudra Hindia diidentifikasi berada dalam kondisi sehat dimana tidak mengalami lebih tangkap (overfished) dan kelebihan upaya penangkapan (overfishing). Di Indonesia, tongkol merupakan komoditas ekspor dengan tujuan utama yaitu Thailand, Jepang, dan Filipina (Anonim, 2019). Berdasarkan Statistik Perikanan Tangkap yang dikeluarkan oleh Kementerian Kelautan dan Perikanan, total tangkapan tuna neritik mencapai 6,5 juta ton dalam kurun waktu 2006 - 2016. Diantara jumlah tersebut, tangkapan tongkol komo berkontribusi sebesar $28 \%$, diikuti oleh tongkol krai $27 \%$, tenggiri $22 \%$, tongkol abu-abu $16 \%$, tenggiri papan $4 \%$, dan tongkol lisong $3 \%$. Tangkapan tongkol komo cenderung meningkat dalam kurun waktu tersebut, yaitu 118 ribu ton pada 2006 meningkat $60 \%$ menjadi 190 ribu ton pada 2016.

Tingginya kebutuhan pasar berakibat pada meningkatnya tekanan penangkapan pada sumber daya perikanan (Widodo \& Suadi, 2008). Oleh karena itu, suatu kajian secara kuantitatif diperlukan untuk menentukan status stok guna menyusun strategi pengelolaan yang efektif. Kondisi yang terjadi bahwa ketersediaan informasi tentang dinamika populasi dan pemanfaatan tongkol komo di perairan Indonesia masih terbatas. Padahal, basis ilmiah tentang dinamika penangkapan, ukuran, dan populasi sangatlah diperlukan dalam menentukan status stok (Sparre \& Venema, 1998). Terlebih lagi, dalam penerapan kebijakan berbasis Wilayah Pengelolaan Perikanan (WPP) di mana status stok perlu disusun untuk setiap WPP sebagaimana dijelaskan dalam Keputusan Menteri Kelautan dan Perikanan Republik Indonesia Nomor 107/KEPMEN-KP/2015 tentang Rencana Pengelolaan Perikanan Tuna, Cakalang dan Tongkol. Oleh karena itu, beberapa penelitian telah difokuskan pada investigasi aspek biologi reproduksi dan pendugaan musim pemijahan (Amri et al., 2018; Ekawaty \& Jatmiko, 2018; Hidayat et al., 2016), serta dinamika populasi di beberapa perairan, seperti di Laut Jawa (Chodrijah et al., 2013), barat Sumatra (Jatmiko et al., 2014) dan Selat Malaka (Wagiyo et al., 2017).

Dalam rangka mengkaji stok ikan, Komisi Nasional Pengkajian Stok Ikan (Komnaskajiskan) di bawah Menteri Kelautan dan Perikanan telah memasukkan analisis rasio potensi pemijahan berbasis ukuran panjang (length-based spawning potential ratio atau LB-SPR) sebagai indikator kelestarian stok sejak tahun 2015 (Ernawati et al., 2017). SPR merupakan indeks relatif tingkat reproduksi dalam kondisi perikanan yang dieksploitasi (Hordyk et al., 2015a, b). Prinsip dasar SPR adalah membandingkan proporsi potensi pemijahan dari sumber daya ikan yang tidak tertangkap atau tersisa dari tekanan penangkapan. Stok ikan yang tidak tertangkap memiliki SPR ${ }_{100 \%}$, sedangkan tekanan penangkapan akan mengurangi $\mathrm{SPR}_{100 \%}$ hingga ke level tertentu $\left(S^{2} R_{x \%}\right)$ (Prince et al., 2015a,b). Penelitian ini bertujuan untuk mengestimasi parameter populasi tongkol komo, meliputi parameter pertumbuhan, mortalitas, pola rekrutmen, dan laju eksploitasi. Dalam penelitian ini juga mengikutsertakan analisis SPR dalam rangka menyediakan titik acuan biologi (biological reference points atau BRP) sebagai landasan ilmiah untuk menilai kondisi stok tongkol komo dalam merespon tekanan penangkapan di Samudra Hindia, khususnya di perairan Lombok dan sekitarnya.

\section{BAHAN DAN METODE Pengumpulan Data}

Lokasi pengumpulan data difokuskan di Pelabuhan Perikanan Tanjung Luar, Lombok Timur pada Januari hingga Desember 2016. Tanjung luar merupakan salah satu pusat pendaratan utama bagi perikanan TCT di Lombok, selain Labuhan Lombok (Setyadji \& Nugraha, 2015). Ukuran panjang tongkol komo dikumpulkan secara acak setiap bulannya dan dikombinasikan dari hasil tangkapan berbagai armada 
perikanan skala kecil, seperti pancing ulur dan tonda, jaring insang, serta pukat cincin yang beroperasi pada area $8^{\circ} 44^{\prime}$ ' hingga $11^{\circ} 15^{\prime}$ LS dan $116^{\circ} 15^{\prime}$ ' hingga $120^{\circ} 40^{\prime}$ BT (Gambar 1). Total 1.321 data ukuran panjang cagak (fork length, satuan $\mathrm{cm}$ ) ikan diperoleh dengan menggunakan kaliper dengan ketelitian $0,1 \mathrm{~cm}$. Kemudian data panjang cagak tersebut dikompositkan menjadi satu ukuran kelas panjang dan membentuk distribusi frekuensi panjang bulanan.

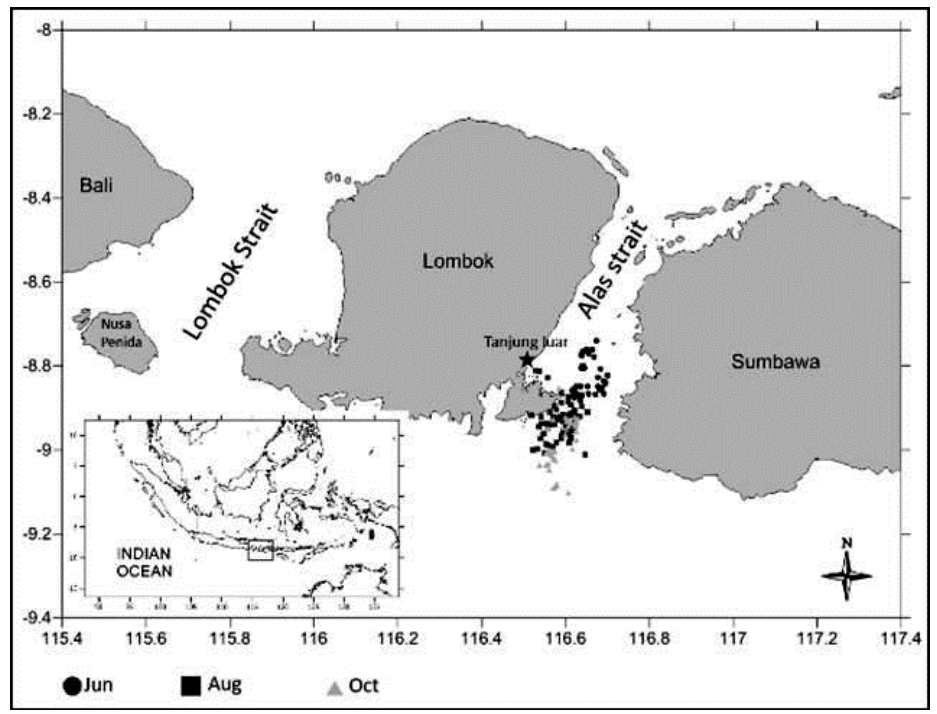

Gambar 1. Peta pengumpulan sampel di Tanjung Luar. Tanda lingkaran, persegi dan segitiga mengindikasikan posisi pengoperasian alat tangkap pancing ulur dan tonda yang diperoleh dari GPS saat observasi ilmiah diatas kapal secara berturut-turut pada Juni, Agustus, dan Oktober 2016.

Figure 1. Map of the sampling site at Tanjung Luar. The setting locations of small-scale troll and handline were gathered from the GPS during scientific on-board observations on June, August, and October 2016 marked by circles, squares, and triangle respectively.

\section{Analisis Data Pertumbuhan}

Pertumbuhan ikan tongkol komo diestimasi menurut Fungsi Pertumbuhan von Bertalanffy (von Bertalanffy Growth Function atau VBGF) berdasarkan nilai parameter pertumbuhan meliputi panjang asimptotik ( $\mathrm{L}_{\infty}$, satuan $\left.\mathrm{cm}\right)$, koefisien pertumbuhan $\left(\mathrm{k}\right.$, satuan tahun $\left.^{-1}\right)$, dan umur teoritis, yaitu umur saat ikan mencapai ukuran 0 ( $\mathrm{t}_{0}$, satuan tahun). Estimasi parameter $\mathrm{L}_{\infty}$ dan $\mathrm{k}$ dilakukan dengan analisis Electronic Length Frequency Analysis (ELEFAN) dengan paket TropfishR (Mildenberger et al., 2017) pada perangkat lunak R-Statistical Program versi 3.6.3 (R Core Team, 2020). Pertumbuhan ikan dapat dimodelkan dengan kurva regresi non linier VBGF sehingga ukuran panjang ikan pada saat umur tertentu (length at age atau $\mathrm{L}_{\mathrm{t}}$, satuan $\mathrm{cm}$ ) dapat diestimasi berdasarkan persamaan yang dilaporkan oleh Sparre \& Venema, (1998), yaitu:

$L_{t}=L\left(1-e^{-k(t-t 0)}\right)$

Umur teoritis $\left(\mathrm{t}_{0}\right)$ dikalkulasi berdasarkan persamaan empriris yang dijelaskan oleh Pauly (1984), yaitu:

$$
\log \left(-t_{0}\right)=-0.392-0.275 \log L_{\infty}-1.038 \log k
$$

Masa hidup (life span atau longevity) ikan, yaitu ukuran panjang cagak dan umur maksimum yang bisa dicapai, diestimasi dengan formula menurut (Froese \& Pauly, 2000):

$L_{t \max }=L_{\infty} * 95 \%$ dan $t_{\max }=3 / k+t_{0}$

Lebih jauh, menurut (Pauly \& Munro, 1984), parameter pertumbuhan $L_{\infty}$ dan $k$ dapat dikombinasikan kedalam indeks tunggal, yaitu indeks performa pertumbuhan atau growth performance index $(\phi ')$ melalui persamaan:

$\phi^{\prime}=\log _{10}(k)+2 \log _{10}\left(L_{\infty}\right)$

\section{Mortalitas}

Mortalitas alami (M, satuan tahun $\left.{ }^{-1}\right)$ merupakan salah satu parameter kunci dari pendugaan lifehistory. Nilai $\mathrm{M}$ diestimasi dengan menggunakan fungsi M_empirical dalam paket TropfishR (Mildenberger et al., 2017). Nilai M dihitung ketika 
$\mathrm{t}_{\max }$ tersedia menggunakan modifikasi dari formula yang dilaporkan Hoenig, (1983). Formula yang telah dimodifikasi tersebut dilaporkan oleh Then et al. (2015), yaitu:

$M=4.899 * t_{\max }^{0.916}$

Selanjutnya, menurut Pauly (1983), nilai M yang diperoleh perlu dikoreksi dengan koefisien sebesar 0.8 untuk jenis ikan-ikan pelagis yang hidup berkelompok. Mortalitas total $\left(Z\right.$, satuan tahun $^{-1}$ ) diestimasi dengan metode kurva linier hasil konversi tangkapan dari ukuran panjang (linearized lengthconverted catch curve) dengan penambahan argumen catchCurve dalam paket TropfishR (Mildenberger et al., 2017). Selanjutnya, mortalitas penangkapan (F, satuan tahun ${ }^{-1}$ ) dihitung dengan mengurangkan $Z$ dengan M menurut persamaan Sparre \& Venema (1998), yaitu Z = F+M. Variasi nilai F juga diidentifikasi pada setiap ukuran panjang dengan menggunakan analisis populasi virtual (Virtual Population Analysis atau VPA) dengan mengoperasikan fungsi VPA didalam paket TropfishR (Mildenberger et al., 2017).

\section{Rekrutmen}

Rekrutmen (dalam satuan \%) ditentukan ketika generasi baru berinteraksi dengan perikanan, ditandai dengan tertangkapnya ikan-ikan berukuran kecil oleh alat penangkapan ikan. Pendugaan periode rekrutmen dilakukan dengan dengan paket TropFishR pada perangkat lunak $R$ dengan memasukkan fungsi recruitment berdasarkan data frekuensi panjang bulanan selama satu tahun (Mildenberger et al., 2017).

\section{Laju Eksploitasi dan Rasio Potensi Pemijahan atau Spawning Potential Ratio (SPR)}

Laju eksploitasi (E) atau pemanfaatan sumber daya dihitung dengan persamaan Pauly (1984), yaitu $\mathrm{E}=\mathrm{F} / \mathrm{Z}$. Rasio potensi pemijahan atau diestimasi berdasarkan data frekuensi panjang (length-based spawning potential ratio atau LB-SPR) yang dikombinasikan dari alat-alat penangkapan ikan. Ukuran rata-rata ikan yang tertangkap (Selectivity length atau SL) dihitung dengan kurva logistik sesuai pendekatan selektivitas pada jaring trawl berdasarkan persamaan menurut Sparre \& Venema (1998), yaitu:

$$
S L=\frac{1}{1+\exp (a-b * L)}
$$

dimana a adalah nilai intersep dan b merupakan kemiringan (slope) dari persamaan linier:

$$
L n=\frac{1}{(S L-1)}=a-b L, \text { jadi } S L_{50}=-a / b
$$

SPR ditentukan dengan paket LBSPR ver 0.1.5 (Hordyk, 2019), pada perangkat lunak R-Statistical Program versi 3.6.3 (R Core Team, 2020). Beberapa parameter life-history diperlukan untuk analisis SPR, seperti ratio $\mathrm{F} / \mathrm{M}$ dan $\mathrm{M} / \mathrm{k}$ yang dihasilkan dalam penelitian ini. Parameter biologi lainnya, seperti ukuran saat rata-rata populasi matang gonad $\left(L_{50}\right)$ dan ukuran saat seluruh populasi matang gonad $\left(\mathrm{L}_{95}\right)$, serta koefisien a dan b dari hubungan panjang-bobot, juga digunakan dalam analisis SPR dan disintesis dari penelitian sebelumnya oleh Ekawaty \& Jatmiko (2018) dan Agustina et al., (2018). SPR dihitung sesuai tingkat rasio $\mathrm{F} / \mathrm{M}$ serta $\mathrm{M} / \mathrm{k}$ dengan menggunakan persamaan empiris menurut Hordyk et al. (2015b), yaitu:

$$
S P R=\frac{\sum\left(1-\bar{L}_{x}\right)^{(M / k[(F / M)+1])} \bar{L}_{x}^{b}}{\sum\left(1-\bar{L}_{x}\right)^{M / k} \bar{L}_{x}^{b}} \text { untuk } \mathrm{x}_{\mathrm{m}} \leq \mathrm{x} \leq 1 \ldots(8)
$$

dimana $\tilde{L}_{x}$ merupakan panjang cagak yang terstandarisasi pada umur terstandarisasi $\mathrm{x}$, sedangkan $b \approx 3$ (Hilborn \& Walters, 1992 dalam Hordyk et al., 2015b).

LB-SPR merupakan model yang dibangun berbasis equilibrium atau keseimbangan. Asumsi yang digunakan dalam model ini adalah panjang sampel mewakili populasi, stok berada pada atau mendekati titik keseimbangan, dan selektivitas bersifat asimptotik dimana ukuran ikan dewasa semuanya telah ditangkap (Hordyk et al., 2015b). Model LB-SPR menggunakan SPR $_{20 \%}$ sebagai batas titik acuan (limit reference point atau $L R P$ ) dimana potensi reproduksi perlu dipertahankan untuk menjaga rekrutmen di tahun berikutnya serta SPR ${ }_{40 \%}$ sebagai sasaran titik acuan (target reference point atau TRP) yang diharapkan agar sumberdaya perikanan lestari (Bunnell \& Miller, 2005; Hordyk et al., 2015a, Prince et al., 2015b).

\section{HASIL DAN BAHASAN Hasil}

\section{Struktur Ukuran}

Total sebanyak 1.321 ekor sampel tongkol komo diperoleh dari hasil tangkapan berbagai alat penangkapan ikan dan diukur panjang cagaknya pada periode penelitian. Ukuran tongkol komo berkisar antara 21,0 hingga $77,0 \mathrm{~cm}$ dengan rata-rata adalah $51,6 \pm 10 \mathrm{~cm}$. Secara keseluruhan, distribusi ukuran tongkol komo menunjukkan pola modus tunggal yaitu diantara ukuran 60 hingga $62 \mathrm{~cm}$. Apabila dibandingkan dengan nilai $\mathrm{L}_{50}=48,4 \mathrm{~cm}$, maka sebanyak $71 \%$ diantaranya diidentifikasi berukuran lebih besar dari $L_{50}$ (Gambar 2). 


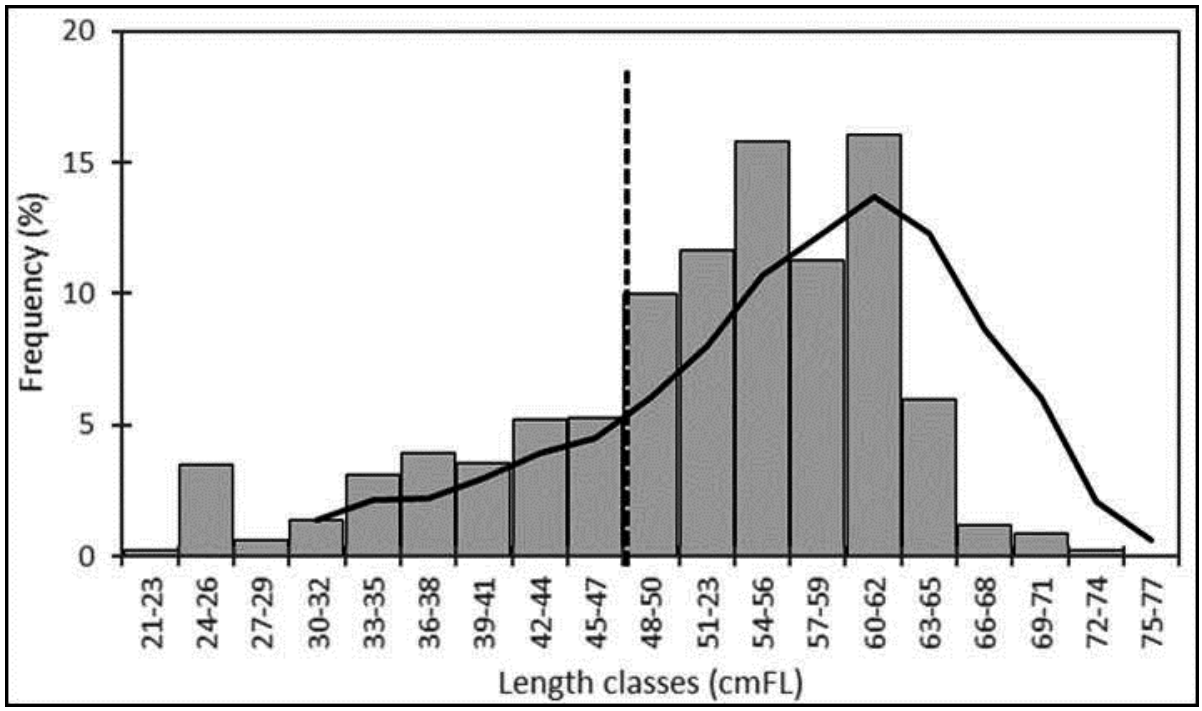

Gambar 2. Distribusi frekuensi panjang cagak tongkol komo yang tertangkap oleh perikanan skala kecil. Garis hitam putus-putus menunjukkan ukuran rata-rata populasi saat matang gonad $\left(L_{50}\right)=48,4$ $\mathrm{cm}$ dan garis hitam solid menunjukkan sebaran normalitas data yang cenderung ke kanan berdasarkan gabungan berbagai alat tangkap.

Figure 2. The aggregated length-frequency distributions of kawakawa caught by small-scale fisheries in Lombok. The black dash line indicates $L_{50}=48.4 \mathrm{~cm}$, while the solid line indicates a right-skewed data normality distribution based on multi gears landing.

\section{Parameter Pertumbuhan}

Estimasi parameter pertumbuhan tongkol komo dilakukan pada kondisi tanpa pemisahan jenis kelamin (pooled). Pertumbuhan membentuk kurva regresi nonlinier dengan persamaan $L_{t}=85,0\left(1-\mathrm{e}^{-0,7}(\mathrm{t}+0,173)\right)$ (Gambar 3a). Berdasarkan nilai panjang asimptotik $\left(L_{\infty}\right)$ dan koefisien pertumbuhan $(k)$, dapat diestimasi bahwa indeks performa pertumbuhan atau growth performance index ( $\left.\phi^{\prime}\right)$ tongkol komo adalah 3,70. Masa hidup (life span atau longevity) tongkol komo mampu mencapai ukuran panjang cagak dan umur maksimal masing-masing $80,75 \mathrm{~cm}$ dan 4,29 tahun. Sebagai hasilnya, ukuran panjang cagak tongkol komo mencapai $47,6 \mathrm{~cm}, 66,4 \mathrm{~cm}, 75,8 \mathrm{~cm}$, dan 80,4 saat umur 1, 2, 3 dan 4 tahun secara berturut-turut.
Kurva pertumbuhan von Bertalanffy dapat direkonstruksi pada distribusi bulanan frekuensi panjang cagak seperti disajikan pada Gambar 3b. Distribusi bulanan frekuensi panjang cagak menunjukkan adanya pergeseran modus ukuran ikan dari bulan ke bulan yang mengindikasikan pertumbuhan populasi.

\section{Pola Rekrutmen}

Pola rekrutmen tongkol komo di perairan selatan Lombok membentuk dua puncak dalam setahun. Puncak pertama sekaligus yang tertinggi diidentifikasi pada Juli (12,19\%). Sedangkan puncak kedua terjadi pada November $(11,88 \%)$ (Gambar 4). 

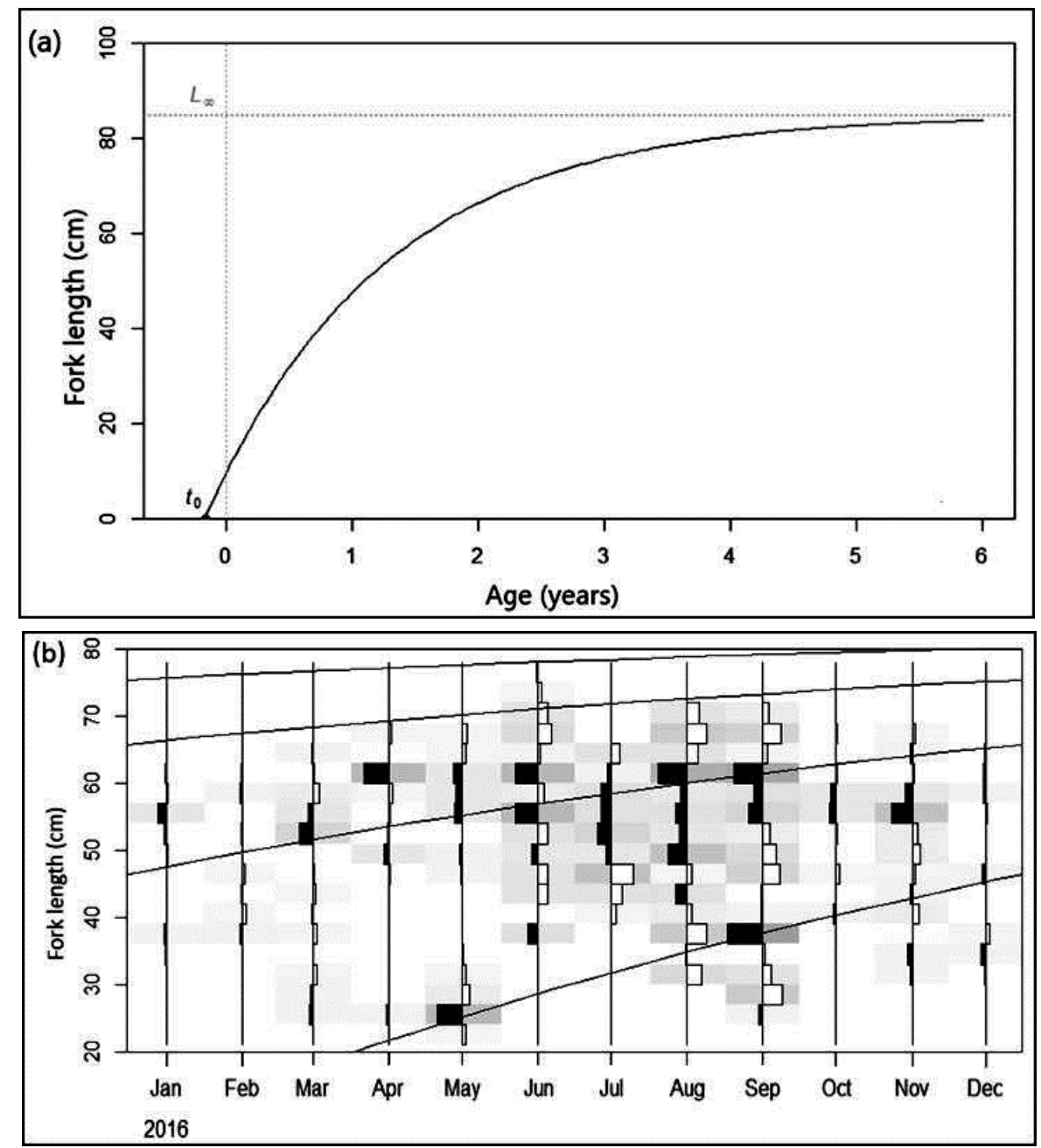

Gambar 3. (a) Kurva pertumbuhan von Bertalanffy tongkol komo yang dikonstruksi dari persamaan $L_{t}=85,0$ $\left(1-\mathrm{e}^{-0,7(t+0,173)}\right)$. Garis putus-putus abu-abu mengindikasikan $\mathrm{L}_{\infty}=85,0 \mathrm{~cm}$; (b) rekonstruksi distribusi bulanan frekuensi panjang bulanan tongkol komo dengan kurva pertumbuhan von Bertalanffy.

Figure 3. (a) The Von Bertalanffy growth curve of kawakawa constructed from an equation $L_{t}=85,0\left(1-e^{-0,7}\right.$ $\left({ }^{(t+0,173))}\right.$. The grey dash line indicates $L_{\infty}=85,0 \mathrm{~cm}$; (b) monthly length-frequency distributions (LFDs) of kawakawa reconstructed using von Bertalanffy growth curves.

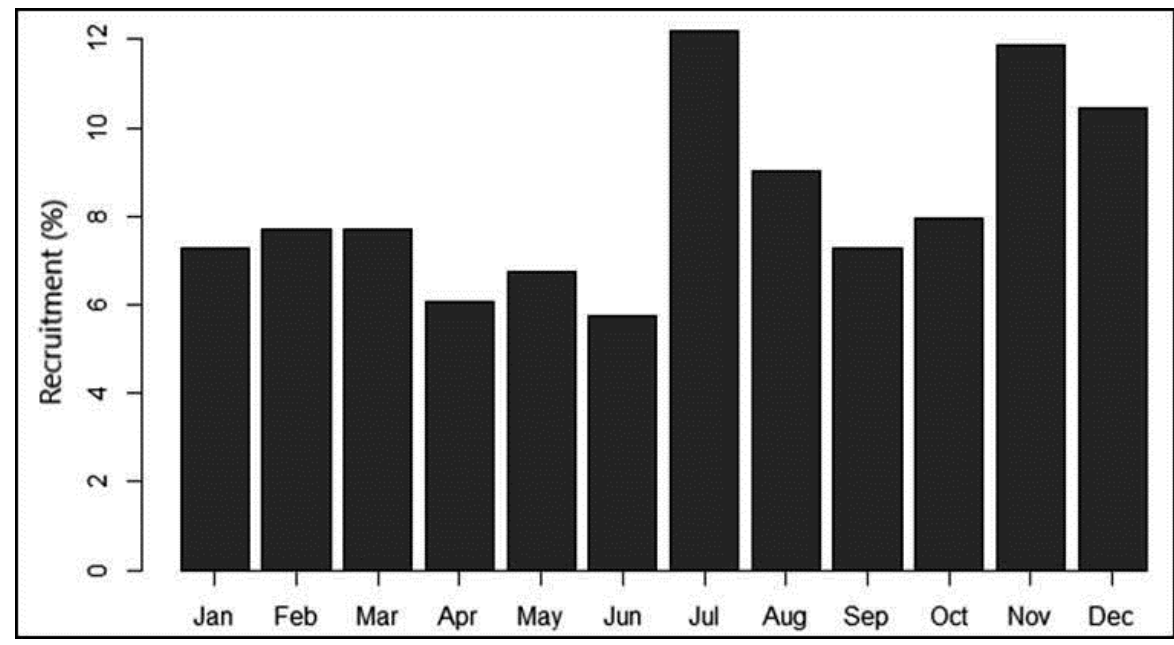

Gambar 4. Pola rekrutmen tongkol komo di perairan selatan Lombok dan sekitarnya pada 2016.

Figure 4. Recruitment pattern of kawakawa in the southern Lombok and adjacent waters in 2016 


\section{Laju Kematian dan Tingkat Pemanfaatan}

Laju kematian total (Z) diperoleh nilai 3,39 tahun $^{-1}$ yang dihasilkan dari kurva linier hasil konversi tangkapan dari ukuran panjang atau linearized lengthconverted catch curve (Gambar 5a). Laju kematian alami (M) adalah 1,07 tahun ${ }^{-1}$ dengan memasukkan nilai $t_{\max }$. Sebagai hasilnya, laju kematian akibat penangkapan (F) diperoleh 2,32 tahun ${ }^{-1}$ dengan mengurangkan nilai $Z$ dengan $M$. Sementara itu, laju eksploitasi (E) didapatkan sebesar 0,68.

Hasil analisis VPA menunjukkan bahwa faktor kematian alami mendominasi saat ukuran panjang cagak berkisar 18 hingga $36 \mathrm{~cm}$. Tongkol komo mulai rentan terhadap tekanan penangkapan pada ukuran $37 \mathrm{~cm}$, ditandai dengan semakin meningkatnya proporsi ikan yang tertangkap serta nilai $F$. Nilai $F=$ 0,36 tahun $^{-1}$ pada kelas panjang $45-48 \mathrm{~cm}$ meningkat 2 kali lipat pada kelas panjang $48-51 \mathrm{~cm}^{-0,72 \text { tahun }^{-}}$ 1). Ukuran yang paling rentan ditangkap berkisar antara 60 hingga $63 \mathrm{~cm}$ (midlength $61,5 \mathrm{~cm}$ ), ditandai dengan nilai $\mathrm{F}$ mencapai puncaknya $\left(1,81\right.$ tahun $\left.^{-1}\right)$. Selain itu, pada kelas panjang tersebut, proporsi sintasan (survivors) dibandingkan dengan gabungan populasi yang tertangkap ditambah kematian alami (natural loses) adalah seimbang (Gambar 5b).
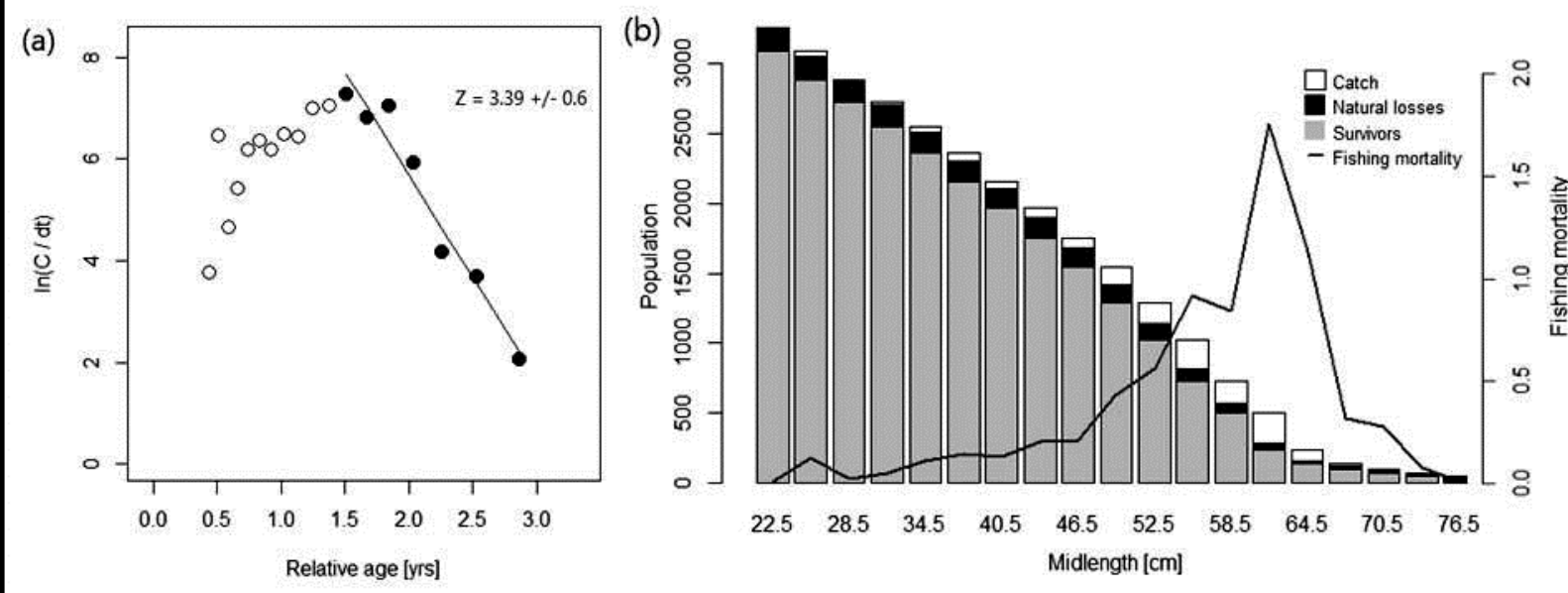

Gambar 5. (a) kurva linier hasil konversi tangkapan dari ukuran panjang tongkol komo. Lingkaran hitam solid mengindikasikan data yang digunakan untuk analisis mortalitas total; (b) Analisis kohort berbasis ukuran panjang yang menunjukkan rekonstruksi struktur populasi (tangkapan, sintasan, dan kematian alami) dan laju kematian penangkapan per kelas panjang.

Figure 5. (a) Linearized length-converted catch kurve of kawakawa. Black circle indicates range of data used for the analysis of total mortality; (b) length-based cohort analysis (CA) shown reconstructed population structure (catch, survivors, and natural losses) and fishing mortality rate by length class.

\section{Rasio Potensi Pemijahan atau Spawning Potential Ratio(SPR)}

SPR tongkol komo diestimasi berada pada tingkatan nilai $23 \%$ saat rasio $\mathrm{F} / \mathrm{M}$ dan $\mathrm{M} / \mathrm{k}$ masingmasing adalah 2,15 dan 1,53. Nilai SPR ini mendeskripsikan perbandingan ikan dewasa yang tertangkap (fished) dan yang tidak tertangkap atau unfished (Gambar 6a). Tingkatan SPR ini dikontribusikan oleh ukuran rata-rata tertangkap (selectivity length atau $\mathrm{SL}_{50}$ ) yaitu $48,69 \mathrm{~cm}$ yang lebih besar dari pada ukuran rata-rata matang gonad (maturity length atau $L_{50}$ ) yaitu $48,4 \mathrm{~cm}$ (Gambar $6 b$ ). SPR $23 \%$ menunjukkan nilai $\mathrm{F}_{\text {current }}=2,32$ tahun $^{-1}$ lebih besar daripada batas minimum titik acuan (limit reference point atau LRP), yaitu $\mathrm{F} / \mathrm{M}=1$ serta sasaran titik acuan (target reference point atau TRP), yaitu $\mathrm{F}$ $=2 / 3 \mathrm{M}$ sehingga menurunkan level penambahan hasil relatif (relative yield recruit) dan biomassa stok pemijahan (spawning stok biomass atau SSB) dari tingkatan lestari (Gambar 6c). 


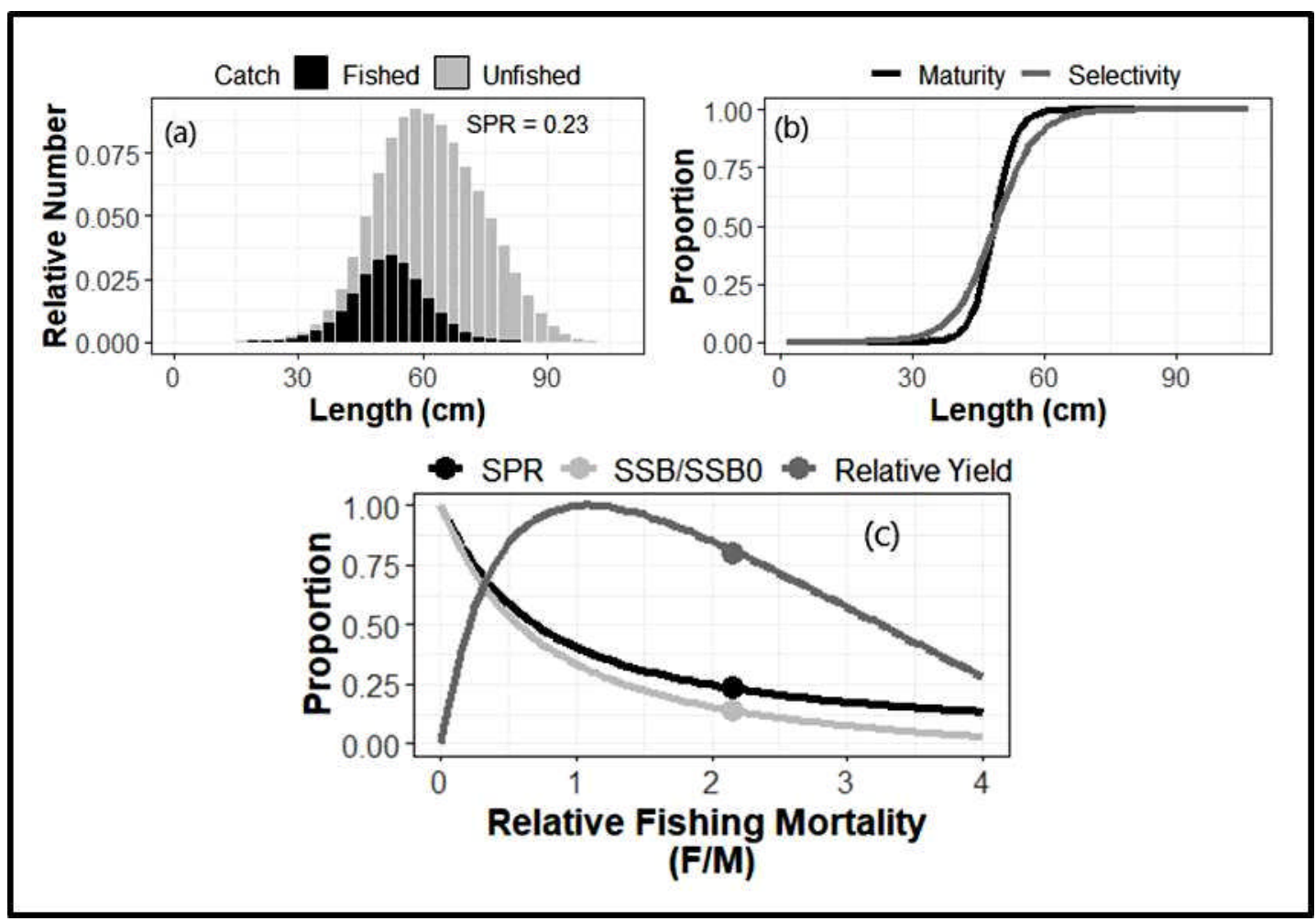

Gambar 6. (a) Proporsi struktur ukuran tongkol komo yang tertangkap dan tidak tertangkap pada kondisi SPR 23\%; (b) perbandingan antara ukuran rata-rata matang gonad dan rata-rata tertangkap; (c) kurva SPR dan penambahan hasil relatif sebagai fungsi dalam berbagai tingkat mortalitas penangkapan relatif.

Figure 6. (a) The size structure proportion of the fished and unfished of kawakawa under current level of SPR at 23\%; (b) the comparison of maturity and selectivity size curves; (c) the SPR and relative yield curves in various relative fishing mortality level.

\section{Bahasan}

Tercatat bahwa perikanan skala kecil berkontribusi $80 \%$ hasil tangkapan perikanan di Indonesia (Mous et al., 2005), namun pengkajian stok secara kuantitatif untuk menilai status perikanan masih terkendala karena terbatasnya data tangkapan dan upaya yang runtut, kelimpahan populasi, dan kondisi demografi (Ault et al., 2008; Dowling et al., 2015). Penelitian ini mengungkap struktur ukuran dan dinamika populasi, serta penggunaan titik acuan biologi dalam menentukan kondisi kesehatan stok ikan ditengahtengah keterbatasan data pada perikanan skala kecil. Pengkajian stok berdasarkan data frekuensi panjang banyak digunakan karena lebih hemat biaya dan mudah dikumpulkan (Brooks et al., 2010; Mildenberger et al., 2017). Terlebih lagi, di perairan tropis di mana pertumbuhan ikan tidak tergambarkan secara jelas pada otolith dan jaringan keras lainnya, seperti sisik, tulang belakang, dan duri akibat konsekuensi dari suhu perairan yang hangat dan stabil sepanjang tahun (Pauly, 1984; Sparre \& Venema, 1998).

\section{Parameter Pertumbuhan}

Penelitian ini mengungkap bahwa pertumbuhan tongkol komo berlangsung cepat pada tahun pertama. Setelah itu, pertumbuhan ukuran per tahun melambat seiring dengan bertambahnya umur. Model pertumbuhan von Bertalanffy mengungkap pertumbuhan tongkol komo tergolong lambat, ditandai dengan nilai koefisien pertumbuhan $(\mathrm{k})$ kurang dari 1 (Sparre \& Venema, 1998). Namun demikian, membandingkan pertumbuhan ikan hanya dari parameter tunggal ( $L_{\infty}$ atau $k$ saja) akan menyesatkan (Pauly, 1979). Nilai $L_{\infty}$ dan $k$ menunjukkan hubungan yang berkebalikan, yaitu semakin kecil nilai k mempunyai konsekuensi pada $\mathrm{L}_{\infty}$ dan umur yang semakin panjang dan juga berlaku sebaliknya (Pauly, 1980). Oleh karena itu, indeks performa pertumbuhan ( $\phi$ ') lebih relevan digunakan untuk membandingkan pertumbuhan intra-spesies dan inter-spesies dalam familia yang sama (Munro \& Pauly, 1983; Pauly \& Munro, 1984). Nilai \$' pada penelitian ini $(3,70)$ termasuk ke dalam kisaran nilai $\phi$ ' yang dilaporkan oleh penelitian sebelumnya (Tabel 1 ). 
Tabel 1. Ringkasan hasil estimasi parameter pertumbuhan tongkol komo dari berbagai perairan tropis Table 1. Summary of the estimated growth parameters of kawakawa from various tropical seas

\begin{tabular}{|c|c|c|c|c|c|}
\hline $\begin{array}{l}\text { Lokasi / } \\
\text { Localities }\end{array}$ & $\begin{array}{c}\mathrm{L}_{\infty} \\
(\mathbf{c m})\end{array}$ & $\begin{array}{c}\mathbf{k} \\
\left(\operatorname{tahun}^{-1}\right)\end{array}$ & $\begin{array}{c}t_{0} \\
\text { (tahun) }\end{array}$ & $\phi$ & $\begin{array}{l}\text { Sumber / } \\
\text { Sources }\end{array}$ \\
\hline Selat Malaka, Indonesia & 64,25 & 0,96 & $\mathrm{n} / \mathrm{a}$ & 3,60 & Wagiyo et al. (2017) \\
\hline $\begin{array}{l}\text { Samudra Hindia barat } \\
\text { Sumatra, Indonesia }\end{array}$ & 63,5 & 0,63 & $-0,21$ & 3,40 & Jatmiko et al. (2014) \\
\hline Laut Jawa, Indonesia & 59,63 & 0,91 & 0,178 & 3,51 & Chodrijah et al. (2013) \\
\hline Dar es Salaam, Tanzania & 89,25 & 0,78 & $\mathrm{n} / \mathrm{a}$ & 3,79 & $\begin{array}{l}\text { Johnson \& Tamatamah } \\
(2013)\end{array}$ \\
\hline Pesisir India & 81,92 & 0,56 & $-0,0317$ & 3,57 & Rohit et al. (2012) \\
\hline $\begin{array}{l}\text { Teluk Persia dan Laut } \\
\text { Oman, Iran }\end{array}$ & 87,66 & 0,51 & $-0,23$ & 3,59 & Motlagh et al. (2010) \\
\hline Pesisir barat India & 72,5 & 0,56 & -0.0327 & 3,47 & Ghosh et al. (2010) \\
\hline Maharashtra, India & 81,7 & 0,79 & $\mathrm{n} / \mathrm{a}$ & 3,72 & Khan (2004) \\
\hline $\begin{array}{l}\text { Samudra Hindia selatan } \\
\text { Lombok, Indonesia }\end{array}$ & 85,0 & 0,70 & $-0,173$ & 3,70 & Penelitian ini \\
\hline
\end{tabular}

n/a: data tidak tersedia/data not available

Performa pertumbuhan tongkol komo pada penelitian ini lebih tinggi apabila dibandingkan dengan penelitian sebelumnya di Iran, India, maupun perairan lainnya di Indonesia (Tabel 2). Tongkol komo dari perairan selatan Lombok mampu mencapai ukuran yang lebih panjang daripada populasi tongkol komo di perairan lainnya pada umur yang sama. Sebagai konsekuensinya, masa hidup (life span atau longevity) tongkol komo pada penelitian ini lebih panjang dibandingkan populasi lainnya. Namun demikian, performa pertumbuhan pada penelitian ini lebih kecil daripada yang dilaporkan dari perairan India (Khan, 2004).

Perbedaan performa pertumbuhan mengindikasikan perbedaan life-history populasi tongkol komo yang dipengaruhi oleh kondisi lingkungan, ketersediaan nutrisi dan kompetisi (Ghosh et al., 2010). Lebih lanjut, suhu perairan dan sirkulasi pasang surut air laut berpengaruh pada perbedaan performa pertumbuhan ikan berkaitan dengan ketersediaan makanan (Lee et al., 2012; Park et al., 2008). Berkaca pada fakta bahwa tongkol komo hidup di perairan tropis, maka diduga faktor ketersediaan makanan yang ditunjang oleh sirkulasi arus laut menjadi faktor utama yang membedakan performa pertumbuhan dibandingkan perairan lainnya. Perairan Lombok merupakan bagian dari Arus Lintas Indonesia (Arlindo) yang menghubungkan Samudra Hindia, lautlaut kepulauan, dan Samudra Pasifik. Arlindo membawa masa air yang kaya akan nutrien dan oksigen, disamping itu juga berperan besar dalam trasportasi larva biota laut (Zamroni et al., 2019). Menurut Jatmiko et al. (2018), perairan selatan Lombok kaya akan larva ikan-ikan familia Scombridae dan Carangidae. Temuan sebaran larva tersebut selaras dengan temuan makanan tongkol komo melalui pengamatan isi lambung antara lain berupa Decapterus spp. (Familia Carangidae) dan Auxis spp, Rastrelligerspp, Scomber spp (Familia Scombridae) (Chiou \& Lee, 2004; Wagiyo et al., 2017). Faktor lain yang mempengaruhi perbedaan performa pertumbuhan adalah intensitas penangkapan, dan strategi pengumpulan sampel seperti periode pengambilan sampel, ukuran sampel ikan dan daerah penangkapan ikan (Moazzam et al., 2005; Motlagh et al., 2010), serta jenis alat tangkap yang digunakan (Ghosh et al., 2016). Dalam penelitian ini, jenis dan selektivitas alat tangkap diduga menjadi faktor utama selain kondisi lingkungan. Tongkol komo di perairan Lombok tertangkap oleh berbagai alat tangkap sehingga diperoleh kisaran ukuran yang lebih lebar. Penggunaan alat tangkap pancing dan jaring insang memungkinkan tertangkapnya ikan dengan ukuran yang lebih besar. Semakin besar ukuran ikan yang tertangkap maka performa pertumbuhan semakin tinggi ditandai besarnya $L_{\infty}$ dan kecilnya $k$ sehingga capaian masa hidup (life span) ikan lebih panjang.

\section{Laju Kematian dan Tingkat Pemanfaatan}

Mortalitas total (Z) pada tongkol komo dikontribusikan oleh mortalitas akibat penangkapan (F) diikuti dengan mortalitas alami (M), yaitu masingmasing 2,32 tahun $^{-1}$ dan 1,07 tahun $^{-1}$. Sebagai konsekuensinya, tekanan penangkapan relatif (rasio F/M) diperoleh sebesar 2,62. Nilai F/M dari penelitian ini termasuk yang tertinggi apabila dibandingkan dengan penelitian sebelumnya (Tabel 2). Hal tersebut diindikasikan dengan bervariasinya alat penangkap ikan yang berinteraksi dengan tongkol komo di perairan Lombok. Perbedaan nilai F/M menunjukkan level penangkapan di suatu perairan yang dipengaruhi oleh kondisi stok dan intensitas penangkapan 
(Koolkalya et al., 2017). Tekanan penangkapan berada pada level optimum apabila $F=M\left(F_{\text {target }}\right)$. Bahkan, dalam rangka mendukung rezim pengelolaan yang lebih konservatif, $F=2 / 3 \mathrm{M}$ (Gulland, 1979) dan $F=0,87$ $M$ seringkali digunakan sebagai batas titik acuan $\left(F_{\text {limit }}\right)$ (Zhou et al., 2012). Dengan demikian, penelitian ini mengungkap bahwa perikanan tongkol berada dalam kondisi eksploitasi berlebih (over-exploited), ditunjukkan dengan nilai F lebih besar dari M (Sparre \& Venema, 1998). Kondisi ini didukung pula dengan tingginya nilai laju pemanfaatan $(E)$, yaitu 0,68 atau melebihi $E=0,5\left(E_{\text {opt }}\right)$ yang mengindikasikan terjadinya eksploitasi berlebih (Gulland, 1983). Berdasarkan VPA, penurunan jumlah populasi ikan berukuran kecil lebih didominasi oleh kematian alami. Sedangkan kematian ikan-ikan dewasa $(>48 \mathrm{~cm}$ ) lebih disebabkan oleh aktivitas penangkapan yang mengindikasikan terjadinya recruitment overfishing. Apabila kondisi ini berlanjut, maka dapat mengganggu kelangsungan stok tongkol komo karena terganggunya rekrutmen ikan-ikan muda ke dalam stok di waktu yang akan datang disebabkan kurangnya ikan-ikan dewasa.

Tabel 2. Ringkasan estimasi laju kematian dan pemanfaatan tongkol komo dari perairan yang berbeda di kawasan tropis

Table 2. Summary of the estimated rate of mortality and exploitation of kawakawa from different waters of tropical areas

\begin{tabular}{|c|c|c|c|c|c|}
\hline $\begin{array}{l}\text { Lokasi / } \\
\text { Localities }\end{array}$ & $\begin{array}{c}\text { M } \\
\left(\operatorname{tahun}^{-1}\right)\end{array}$ & $\begin{array}{c}\mathbf{F} \\
\left(\operatorname{tahun}^{-1}\right)\end{array}$ & $\begin{array}{c}\mathrm{Z} \\
\left(\operatorname{tahun}^{-1}\right)\end{array}$ & $\mathrm{E}$ & $\begin{array}{l}\text { Sumber / } \\
\text { Sources }\end{array}$ \\
\hline Selat Malaka, Indonesia & 1,38 & 1,41 & 2,79 & 0,50 & Wagiyo et al. (2017) \\
\hline $\begin{array}{l}\text { Samudra Hindia barat } \\
\text { Sumatra, Indonesia }\end{array}$ & 1,07 & 1,33 & 2,40 & 0,55 & Jatmiko et al. (2014) \\
\hline Laut Jawa, Indonesia & 1,13 & 1,51 & 2,64 & 0,57 & Chodrijah et al. (2013) \\
\hline $\begin{array}{l}\text { Dar es Salaam, } \\
\text { Tanzania }\end{array}$ & 1,09 & 0,69 & 1,78 & 0,38 & $\begin{array}{l}\text { Johnson \& Tamatamah } \\
\text { (2013) }\end{array}$ \\
\hline Pesisir India & 0,93 & 0,75 & 1,68 & 0,36 & Rohit et al. (2012) \\
\hline $\begin{array}{l}\text { Teluk Persia dan Laut } \\
\text { Oman, Iran }\end{array}$ & 0,65 & 1,72 & 2,37 & 0,65 & Motlagh et al. (2010) \\
\hline Pesisir barat India & 0,94 & 0,75 & 1,69 & 0,36 & Ghosh et al.,(2010) \\
\hline $\begin{array}{l}\text { Samudra Hindia selatan } \\
\text { Lombok, Indonesia }\end{array}$ & 1,07 & 2,32 & 3,39 & 0,68 & Penelitian ini \\
\hline
\end{tabular}

\section{Rasio Potensi Pemijahan atau Spawning Potential Ratio (SPR)}

Rasio potensi pemijahan (SPR) tongkol komo berada pada level $23 \%$ pada tingkat tekanan penangkapan relatif (F/M) 2,62. Tingkatan SPR ini lebih kecil jika dibandingkan dengan titik acuan yang diadopsi untuk jenis ikan laut dengan kemampuan resiliensi yang tinggi, yaitu dan $\mathrm{SPR}_{40 \%}$ sebagai TRP (Dorn, 2002). Tingkatan SPR diantara 20-40\% dianggap sebagai produksi telur minimum yang aman untuk memelihara stok ikan (Ault et al., 2008; Nadon et al., 2015). Oleh karena itu, analisis SPR juga diidentikkan dengan permodelan dalam memprediksi jumlah indukan yang mampu mempertahankan kapasitas reproduksi atau disebut biomass stok pemijahan atau spawning stock biomass (SSB). SPR kurang dari $20 \%$ sebagai LRP menyebabkan penurunan stok karena rendahnya jumlah indukan dan produksi telur (Bunnell \& Miller, 2005). SPR pada penelitian ini berada diantara $\mathrm{SPR}_{20 \%}$ dan $\mathrm{SPR}_{40 \%}$ mengindikasikan bahwa eksploitasi perikanan tongkol komo tergolong tinggi.
Penelitian ini mengungkap bahwa rata-rata ukuran tertangkap lebih besar daripada rata-rata matang gonadnya $\left(\mathrm{SL}_{50}>\mathrm{L}_{50}\right)$. Sekilas, banyaknya tongkol komo dewasa yang tertangkap pada penelitian ini mengindikasikan bahwa prinsip kelestarian sumber daya yaitu "setidaknya ikan telah memijah satu kali" telah terpenuhi. Menurut Froese (2004), terdapat tiga prinsip utama agar suatu sumberdaya terhindar dari pemanfaatan berlebih yaitu "(1) biarkan memijah, (2) biarkan tumbuh, dan (3) lindungi indukan". Namun demikian, penelitian ini mencatat bahwa terdapat $71 \%$ ikan berukuran lebih besar dari $\mathrm{L}_{50}=48,4 \mathrm{~cm}$ dan $40 \%$ yang berukuran lebih dari $L_{95}=55,7 \mathrm{~cm}$. Banyaknya indukan yang tertangkap dan didukung pula oleh hasil VPA, justru bertentangan dengan "prinsip kelestarian Froese" yang ketiga. Pada perikanan yang terkelola dengan baik, target laju penangkapan pada indukan adalah $0 \%$ (Filous et al., 2019). Lebih lanjut, ketersediaan indukan 30-40\% dalam stok akan menjamin kelangsungan perikanan, sedangkan kurang dari $20 \%$ menandakan terjadinya eksploitasi berlebih (Froese, 2004). 
Pengelolaan perikanan tongkol komo di kawasan Samudra Hindia dilakukan bersama-sama melalui organisasi pengelolan regional, yaitu Indian Ocean Tuna Commission (IOTC). Saat ini, IOTC belum memberlakukan LRP dan TRP untuk perikanan tongkol komo. Tidak seperti jenis tuna, cakalang, marlin, dan jenis ikan lainnya yg terkait secara ecologi (ecological related species atau ERS) yang dikelola dengan mengadopsi BRP seperti diuraikan dalam Resolusi nomor 15/10 (IOTC, 2019). IOTC menjadikan biomassa pemijahan sebagai acuan dalam pengelolaan sumber daya ikan tersebut, yaitu LRP dan TRP masing-masing ditetapkan pada tingkat $20 \%$ dan $40 \%$ dari level biomass pada kondisi perawan, dimana penangkapan berada pada level nol $\left(\mathrm{SB}_{\mathrm{F}=0}\right)$. Meskipun demikian, terdapat kekhawatiran seiring telah menurunnya hasil tangkapan tongkol komo di kawasan Samudra Hindia dari 168 ribu ton di tahun 2013 menjadi 159 ribu ton pada tahun 2017. IOTC menyarankan agar hasil tangkapan dikurangi menjadi $80 \%$ dari level penangkapan tahun 2013 , yaitu sekitar 135 ribu ton setiap tahunnya sehingga sumberdaya tongkol komo diprediksi akan dapat memulihkan diri di tahun 2023 dengan kemungkinan $50 \%$ (IOTC, 2019). Dalam hal ini, upaya pengelolaan (management measures) yang tepat sangat mendesak untuk dirumuskan guna menjaga kelangsungan stok tongkol komo berdasarkan indikator BRP yang didemonstrasikan dalam penelitian ini dengan pendekatan LB-SPR.

Nilai SPR sensitif terhadap perubahan intensitas tekanan penangkapan (proporsi F/M) sehingga secara tradisional pengambil kebijakan akan mengurangi mortalitas penangkapan agar tidak melebihi mortalitas alaminya yang nilainya diasumsikan konstan, kecuali jika terjadi perubahan yang ekstrim pada lingkungan. Terlebih lagi, nilai $F$ pada penelitian ini lebih besar dua kali lipat daripada nilai M. Dalam hal ini, intensitas penangkapan perlu direduksi hingga pada level $F=M$ yaitu 1,07 tahun $^{-1}$ atau bahkan menyentuh nilai 0,72 tahun $^{-1}$ (penerapan dari $\mathrm{F}_{\text {limit }}=2 / 3 \mathrm{M}$ ) atau 0,93 tahun ${ }^{1}\left(F_{\text {limit }}=0,87 \mathrm{M}\right)$, jika rezim pengelolaan konservatif yang lebih dipilih. Pengendalian tekanan penangkapan dapat ditempuh dengan memvalidasi jumlah upaya penangkapan terkini yang diikuti dengan pengendalian upaya penangkapan misalnya dengan pemberlakuan moratorium penerbitan izin kapal-kapal baru. Oleh karena itu, program pemantauan hasil tangkapan dan upaya penangkapan secara harian yang diinisiasi oleh Kementerian Kelautan dan Perikanan perlu dilaksanakan secara berkesinambungan setiap tahunnya. Penyediaan data yang akurat menjadi tanggung jawab pemerintah dalam mendukung rencana aksi pengelolaan perikanan tongkol yang berkelanjutan seperti diuraikan dalam Keputusan Menteri Kelautan dan Perikanan Republik Indonesia
Nomor 107/KEPMEN-KP/2015 tentang Rencana Pengelolaan Perikanan Tuna, Cakalang dan Tongkol.

Mengacu pada tingginya mortalitas penangkapan pada ikan-ikan dewasa yaitu berukuran $>48 \mathrm{~cm}$ yang diindikasikan dengan $\mathrm{SL}_{50}>\mathrm{L}_{50}$, maka penutupan area penangkapan juga dapat menjadi opsi pengelolaan yang lebih rasional dibandingkan pengaturan penggunaan alat tangkap tertentu. Hal tersebut dikarenakan seluruh alat tangkap yang beroperasi di perairan selatan Lombok turut berkontribusi dalam tingginya penangkapan individu-individu dewasa. Penutupan area penangkapan perlu diberlakukan dalam kurun waktu tertentu saat ikan-ikan dewasa banyak tertangkap. Selain untuk mengurangi upaya penangkapan, penutupan area penangkapan ditujukan pula untuk melindungi indukan-indukan dalam melepaskan telurnya. Menurut Ekawaty \& Jatmiko (2018), periode pemijahan tongkol komo terjadi pada Juni hingga Agustus. Bahkan, musim pemijahan tongkol komo di Samudra Hindia dapat berlangsung lebih lama, yaitu dari Mei hingga Oktober (musim timur hingga musim peralihan II), dikarenakan tongkol komo merupakan tipe pemijah sebagian (partial spawner) dimana ikan tidak melepaskan telurnya secara serentak (Amri et al., 2018; Hidayat et al., 2016). Musim pemijahan ini diindikasikan bersamaan pula dengan musim penangkapan yang dipengaruhi oleh suhu permukaan laut (SPL) yang rendah (Amri et al., 2018).

Opsi penutupan area penangkapan bukan tanpa kendala mengingat tingginya ketidakpastian informasi tentang biologi reproduksi dan pola kebiasaan pemijahan. Oleh karena itu, kajian ilmiah yang komprehensif tentang penandaan (tagging) pada ikan guna melacak pola migrasi, variasi bulanan tingkat kematangan gonad, dan sebaran larva untuk menentukan waktu dan area pemijahan di sekitar perairan Lombok perlu diinisiasi di masa mendatang. Dengan basis data yang menyeluruh, diharapkan dapat diidentifikasi area yang spesifik sebagai daerah pemijahan tongkol komo yang diwujudkan dalam daerah perlindungan (suaka). Perlindungan pada area yang diidentifikasi sebagai daerah pemijahan (spawning ground) dipertimbangkan menjadi salah satu opsi yang rasional untuk menjawab permasalahan recruitment overfishing pada sumberdaya ikan untuk melindungi indukan saat memijah sehingga rekrutment individu-individu baru ke dalam stok dapat meningkat di masa mendatang.

\section{KESIMPULAN}

Pertumbuhan tongkol komo dapat dimodelkan berdasarkan kurva pertumbuhan von Bertalanffy membentuk persamaan $L_{t}=85,0\left(1-e^{-0,7(t+0,173)}\right)$. 
Performa pertumbuhan tongkol komo di perairan Lombok adalah yang tertinggi di perairan Indonesia sehingga berukuran lebih besar dan masa hidupnya lebih panjang. Sebagian besar tangkapan merupakan ikan dewasa ditunjukkan dengan $\mathrm{SL}_{50}>\mathrm{L}_{50}$. Namun, tingginya intensitas penangkapan ikan-ikan dewasa telah mengganggu rekrutmen individu-individu baru ke dalam stok. Beberapa indikator, seperti tekanan penangkapan relatif atau $\mathrm{F} / \mathrm{M}=2,15$, laju pemanfaatan atau $\mathrm{E}=0,68$, dan $\mathrm{SPR}=23 \%$, menunjukkan bahwa pemanfaatan perikanan tongkol tergolong tinggi sehingga memerlukan penyusunan strategi pengelolaan yang efektif untuk mempertahankan kelestarian perikanan.

\section{PERSANTUNAN}

Tulisan ini merupakan hasil dari kegiatan Penelitian Perikanan Tuna di Samudera Hindia di Loka Riset Perikanan Tuna yang didanai DIPA Tahun Anggaran 2016. Penulis mengucapkan terima kasih kepada Bapak Galih Rakasiwi sebagai enumerator dalam pengumpulan data penelitian. Apresiasi juga disampaikan kepada dua reviewer anonim atas saran dan masukan dalam penyusunan artikel ini. Arief Wujdi merupakan kontributor utama dalam tulisan ini.

\section{DAFTAR PUSTAKA}

Agustina, M., Jatmiko, I., \& Sulistyaningsih, R. K. (2018). Pola pertumbuhan dan faktor kondisi tongkol komo, Euthynnus affinis (Cantor, 1849) di perairan Tanjung Luar Nusa Tenggara Barat. BAWAL, 10(3), 179-185. DOI: http://doi.org/ 10.15578/bawal.10.3.2018.179-185

Ahmed, Q., Yousuf, F., Sarfraz, M., Mohammad Ali, Q., Balkhour, M., Safi, S. Z., \& Ashraf, M. A. (2015). Euthynnus affinis (little tuna): fishery, bionomics, seasonal elemental variations, health risk assessment and conservational management. Frontiers in Life Science, 8(1), 71-96. DOI: https://doi.org/ $10.1080 / 21553769.2014 .961617$

Amri, K., Nora, F. A., Ernaningsih, D., \& Hidayat, T. (2018). Reproduksi dan musim pemijahan tongkol komo (Euthynnus affinis) berdasarkan monsun dan suhu permukaan laut di Samudera Hindia selatan Jawa-Nusa Tenggara. BAWAL, 10(2), 155-167. DOI: http://doi.org/10.15578/bawal.10.2.2018.155-167

Anonim. (2019). BKIPM dalam angka 2018 (p. 623). Jakarta: Sekretariat Badan Karantina Ikan, Pengendalian Mutu dan Keamanan Hasil Perikanan.
Ault, J. ., Smith, S. G., Luo, J., Monaco, M. E., \& Appeldoorn, R. S. (2008). Length-based assessment of sustainability benchmarks for coral reef fishes in Puerto Rico. Environmental Conservation, 35(3), 221-231. DOI: https://doi.org/10.1017/ S0376892908005043

Brooks, E. N., Powers, J. E., \& Cortes, E. (2010). Analytical reference points for age-structured models: application to data-poor fisheries. ICES Journal of Marine Science, 67, 165-175. DOI: https:// doi.org/10.1093/icesjms/fsp225

Bunnell, D. B., \& Miller, T. J. (2005). An individualbased modeling approach to spawning-potential per-recruit models: An application to blue crab (Callinectes sapidus) in Chesapeake Bay. Canadian Journal of Fisheries and Aquatic Sciences, 62(11), 2560-2572. DOI: https://doi.org/10.1139/ f05-153

Chiou, W. D., \& Lee, L. K. (2004). Migration of kawakawa Euthynnus affinis in the waters near Taiwan. Fisheries Science, 70(5), 746-757. DOI: https://doi.org/10.1111/j.1444-2906.2004.00867.x

Chodrijah, U., Hidayat, T., \& Noegroho, T. (2013). Estimasi Parameter Populasi lkan Tongkol Komo (Euthynnus affinis ) di Perairan Laut Jawa. BAWAL, 5(3), 167-174. DOI: http://doi.org/10.15578/ bawal.5.3.2013.167-174

Dorn, M. W. (2002). Advice on west coast rockfish harvest rates from bayesian meta-analysis of stock"recruit relationships. North American Journal of Fisheries Management, 22(1), 280-300. DOI: h t t p s : / / d o i . org / $10.1577 / 1548$ 8675(2002)022<0280:AOWCRH>2.0.CO;2

Dowling, N. A., Dichmont, C. M., Haddon, M., Smith, D. C., Smith, A. D. M., \& Sainsbury, K. (2015). Guidelines for developing formal harvest strategies for data-poor species and fisheries. Fisheries $R e$ search, 171, 130-140. DOI: https://doi.org/ 10.1016/j.fishres.2014.09.013

Ekawaty, R., \& Jatmiko, I. (2018). Biologi reproduksi ikan tongkol komo, Euthynnus affinis (Cantor, 1849) di Samudra Hindia bagian timur. Jurnal Iktiologi Indonesia, 18(3), 199-208. DOI: https:// doi.org/10.32491/jii.v18i3.313

Ernawati, T., Sumiono, B., \& Madduppa, H. (2017). Reproductive ecology, spawning potential, and breeding season of blue swimming crab (Portunidae: Portunus pelagicus) in Java Sea, In- 
donesia. Biodiversitas, 18(4), 1705-1713. DOI: https://doi.org/10.13057/biodiv/d180451

Filous, A., Lennox, R. J., Clua, E. E. G., Cooke, S. J., \& Danylchuk, A. J. (2019). Length-based assessment of an artisanal albulid fishery in the South Pacific: a data-limited approach for management and conservation. Marine and Coastal Fisheries: Dynamics, Management, and Ecosystem Science, 11, 519-534. DOI: https://doi.org/10.1002/ mcf2.10097

Froese, R., \& Pauly, D. (2000). Fishbase 2000: Concepts, design and data sources. (p. 344). Los Baños, Laguna, Philippines: ICLARM.

Froese, R. 2004. Keep it simple: three indicators to deal with overfishing. Fish and Fisheries, 5, 8691. DOI: https://doi.org/10.1111/j.14672979.2004.00144.x

Ghosh, S., Pillai, N. G. K., \& Dhokia, H. K. (2010). Fishery, population characteristics and yield estimates of coastal tunas at Veraval. Indian Journal of Fisheries, 57(2), 7-13.

Ghosh, S., Rao, M. V. H., Mahesh, V. U., Kumar, M. S., \& Rohit, P. (2016). Fishery, reproductive biology and stock status of the Indian mackerel Rastrelliger kanagurta (Cuvier, 1817), landed along the north-east coast of India. Indian Journal of Fisheries, 63(2), 33-41. DOI: https://doi.org/10.21077/ ijf.2016.63.2.53399-05

Gulland, J. A. (1983). Fish stock assessment: A Manual of Basic Methods (p. 233). Chicester: FAO/ Wiley Series on Food and Agriculture.

Gulland, J. A. (1979). Report of FAO/IOP workshop on the fishery resources of the western Indian Ocean South of the Equator. IOFC/DEV/7 (pp. 137). Rome: FAO.

Hidayat, T., Febrianti, E., \& Restiangsih, Y. H. (2016). Pola dan musim pemijahan ikan tongkol komo (Euthynnus affinis Cantor, 1850) di Laut Jawa. BAWAL, 8(2), 101-108. DOI: http://doi.org/ 10.15578/bawal.8.2.2016.101-108

Hoenig, J. M. (1983). Empirical use of longevity data to estimate mortality rates. Fishery Bulletin, 82(4), 898-903.

Hordyk, A. (2019). LBSPR: Length-Based Spawning Potential Ratio. R package version 0.1.5. Retrieved from https://cran.r-project.org/package=LBSPR
Hordyk, A., Ono, K., Valencia, S., Loneragan, N., \& Prince, J. (2015a). A novel length-based empirical estimation method of spawning potential ratio (SPR), and test of its performance, for small-scale, data-poor fisheries. ICES Journal of Marine Science, 72(1), 217-231. DOI: https://doi.org/ 10.1093/icesjms/fsu004

Hordyk, A., Ono, K., Sainsbury, K., Loneragan, N., \& Prince, J. (2015b). Some explorations of the life history ratios to describe length composition, spawning per-recruite, and the spawning potential ratio. ICES Journal of Marine Science, 72(1), 204216. DOI: https://doi.org/10.1093/icesjms/fst235

IOTC (Indian Ocean Tuna Commission). (2019). Report of the 22nd Session of the IOTC Scientific Committee. Karachi, Pakistan, 2-6 December 2019. IOTC-2019-SC22-R[E], p. 204.

Jatmiko, I., Rochman, F., \& Arnenda, G. L. (2018). Distribution and abundance of fish larvae in south of Alas Strait, West Nusa Tenggara. ILMU KELAUTAN: Indonesian Journal of Marine Sciences, 23(2), 87-92. DOI: https://doi.org/10.14710/ ik.ijms.23.2.87-92

Jatmiko, I., Sulistyaningsih, R. K., \& Nugroho, D. (2014). Laju pertumbuhan, laju kematian dan eksploitasi ikan tongkol komo, Euthynnus affinis (Cantor 1849), di perairan Samudera Hindia barat Sumatera. BAWAL, 6(2), 69-76. DOI: http:// doi.org/10.15578/bawal.6.2.2014.69-76

Johnson, M. G., \& Tamatamah, A. R. (2013). Length frequency distribution, mortality rate and reproductive biology of kawakawa (Euthynnus affinis-cantor, 1849) in the coastal waters of Tanzania. Pakistan Journal of Biological Sciences, 16(21), 12701278. DOI: https://doi.org/10.3923/ pjbs.2013.1270.1278

Khan, M. Z. (2004). Age and growth, mortality and stock assessment of Euthynnus affinis (Cantor) from Maharashtra waters. Indian Journal of Fisheries, 51(2), 209-213.

Koolkalya, S., Matchakuea, U., \& Jutagate, T. (2017). Growth, population dynamics and optimum yield of Indian mackerel, Rastrelliger kanagurta (Cuvier, 1816), in the eastern Gulf of Thailand. International Journal of Agricultural Technology, 13(7.1), 10651075.

Lee, W.-O., Zhang, M.-M., Oh, C.-W., Baek, J.-M., \& Song, K.-J. (2012). Age and growth of barbel steed 
Hemibarbus labeo in Goe-san Lake in Korea. Fisheries and Aquatic Sciences, 15(4), 353-359. DOI: https://doi.org/10.5657/FAS.2012.0353

Mildenberger, T. K., Taylor, M. H., \& Wolff, M. (2017). TropFishR: an $\mathrm{R}$ package for fisheries analysis with length-frequency data. Methods in Ecology and Evolution, 8(11), 1520-1527. DOI: https:// doi.org/10.1111/2041-210X.12791

Moazzam, M., Badar Osmany, H., \& Zohra, K. (2005). Indian mackerel (Rastrelliger kanagurta) from $\mathrm{Pa}$ kistan. Some aspects of biology and fisheries. Records Zoological Survey of Pakistan, 16, 5875.

Motlagh, S. A. T., Hashemi, S. A., \& Kochanian, P. (2010). Population biology and assessment of kawakawa (Euthynnus affinis) in Coastal Waters of the Persian Gulf and Sea of Oman (Hormozgan Province). Iranian Journal of Fisheries Sciences, 9(2), 315-326. DOI: https://doi.org/10.22092/ ijfs.2018.114076

Mous, P. J., Pet, J. S., Arifin, Z., Djohani, R., Erdmann, M. V., Halim, A., Knight, M., Pet Soede, L., \& Wiadnya, G. (2005). Policy needs to improve marine capture fisheries management and to define a role for marine protected areas in Indonesia. Fisheries Management and Ecology, 12(4), 259268. DOI: https://doi.org/10.1111/j.13652400.2005.00448.x

Munro, J. L., \& Pauly, D. (1983). A simple method for comparing the growth of fishes and invertebrates. ICLARM Fishbyte, 1, 5-6.

Nadon, M. O., Ault, J. S., Williams, I. D., Smith, S. G., \& Dinardo, G. T. (2015). Length-based assessment of coral reef fish populations in the main and Northwestern Hawaiian Islands. PLoS ONE, 10(8), e0133960. DOI: https://doi.org/10.1371/ journal.pone. 0133960

Park, K. D., Kim, J. K., Chang, D. S., Kim, J. II, \& Oh, C. W. (2008). Age and growth of the mudskipper, Scartelaos gigas (perciformes, gobiidae) from Korea. Animal Cells and Systems, 12(4), 305-311. DOI: https://doi.org/10.1080/ 19768354.2008.9647186

Pauly, D. (1979). Gill size and temperature as governing factors in fish growth: a generalization of von Bertalanffy's growth formula. Berichte Aus Dem Institut Für Meereskunde Kiel, 63, 1-156.
Pauly, D. (1980). On the interrelationships between natural mortality, growth parameters, and mean environmental temperature in 175 fish stocks. ICES Journal of Marine Science, 39(2), 175-192. DOI: https://doi.org/10.1093/icesjms/39.2.175

Pauly, D. (1983). Some Simple Methods for the Assessment of Tropical Fish Stocks. FAO Fisheries Technical Papers 254 (p. 52). Rome: FAO.

Pauly, D. (1984). Fish Population Dynamics in Tropical Waters: A Manual for Use With Programmable Calculators (p.325). ICLARM studies and reviews 8. Manila, Philippines: ICLARM.

Pauly, D., \& Munro, J. L. (1984). Once more on growth comparison in fish invertebrates. ICLARM Fishbyte, 2(1), 21.

Prince, J., Hordyk, A., Valencia, S. R., Loneragan, N., \& Sainsbury, K. (2015a). Revisiting the concept of Beverton-Holt life-history invariants with the aim of informing data-poor fisheries assessment. ICES Journal of Marine Science, 72(1), 194-203. DOI: https://doi.org/10.1093/icesjms/fsu011

Prince, J., Victor, S., Kloulchad, V., \& Hordyk, A. (2015b). Length based SPR assessment of eleven Indo-Pacific coral reef fish populations in Palau. Fisheries Research, 171, 42-58. DOI: https:// doi.org/10.1016/j.fishres.2015.06.008

R Core Team. (2020). R:A language and environment for statistical computing. R Foundation for Statistical Computing, Vienna, Austria. Retrieved from https://www.r-project.org/

Rohit, P., Chellappan, A., Abdusssamad, E. M., Joshi, K. K., Said Koya, K. P., Sivadas, M., Ghosh, S., Rathinam, A. M. M., Kemparaju, S., Dhokia, H. K., Prakasan, D., \& Beni, N. (2012). Fishery and bionomics of the little tuna, Euthynnus affinis (Cantor, 1849) exploited from Indian waters. Indian Journal of Fisheries, 59(3), 33-42.

Setyadji, B., \& Nugraha, B. (2015). Dynamics of gears, fleets, catch and fishing season of smallscale tuna fisheries in Labuhan Lombok, West Nusa Tenggara. Ind.Fish.Res.J, 21(2), 99107. DOI: http://doi.org/10.15578/ifrj.21.2.2015.99107

Sparre, P., \& Venema, C. S. (1998). Introduction to tropical fish stock assessment. Part I: Manual. FAO Fisheries Technical Paper 306/1 (p. 407). Rome, Italy: FAO. 
Then, A. Y., Hoenig, J. M., Hall, N. G., \& Hewitt, D. A. (2015). Evaluating the predictive performance of empirical estimators of natural mortality rate using information on over 200 fish species. ICES Journal of Marine Science, 72(1), 82-92. DOI: https://doi.org/10.1093/icesjms/fsu136

Wagiyo, K., Pane, A. R., \& Chodrijah, U. (2017). Parameter populasi, aspek biologi dan penangkapan tongkol komo (Euthynnus affinis Cantor, 1849) di Selat Malaka. J.Lit.Perikan.Ind., 23(4), 287-297. DOI: http://doi.org/10.15578/ jppi.23.4.2017.287-297

Widodo, J., \& Suadi. (2008). Pengelolaan sumberdaya perikanan laut (p.252). Yogyakarta: Gadjah Mada University Press.
Zamroni, A., Kuswoyo, A., \& Chodrijah, U. (2019). Aspek biologi dan dinamika populasi ikan layang biru (Decapterus macarellus Cuvier, 1833) di perairan Laut Sulawesi. BAWAL, 11(3), 137-149. DOI: http://doi.org/10.15578/bawal.11.3.2019.137149

Zhou, S., Yin, S., Thorson, J. T., Smith, A. D. M., \& Fuller, M. (2012). Linking fishing mortality reference points to life history traits: An empirical study. Canadian Journal of Fisheries and Aquatic Sciences, 69(8), 1292-1301. DOI: https://doi.org/ $10.1139 /\{2012-060$ 